\title{
Shifting Ground - Changing Attitudes to the Green Revitalization of New Zealand's Existing Office Buildings
}

\author{
John Bloomfield Storey \\ Centre for Building Performance Research, School of Architecture, Victoria University of Wellington, New Zealand
}

\begin{abstract}
This paper explores the shift in the attitudes of building developer/owners to the incorporation of sustainability measures into office building renovations in New Zealand over the last 7 years, through a series of interviews with a wide range of key industry players and the study of three seminal case study examples. The interviewees uniformly considered that there had been a rapid increase in interest in the green renovation of existing buildings during the period under consideration, due mainly to strong leadership by central government. Significant differences in attitudes to green renovation emerged between the various groups as to whether, and on what terms such developments were likely to occur. The move to green building solutions seems to have continued in New Zealand, despite the world financial crisis and central government's abrogation of its leadership role being replaced by rising tenant expectations and the need for building owners to let their premises in a more competitive leasing environment. The change in attitudes demonstrated is profound. In the earliest of the case study buildings, started on site in 2004, no consideration is given by the developer, owner or design team to sustainability issues and there is no obvious user demand. In the second case, which started on site only one year later, sustainable design is very prominent, but is largely tenant driven, albeit with the active and enthusiastic support of the developer and design team. The final case study building started on site in 2007 is entirely developer/building owner driven and stems from a perception that "green" buildings represent value for money, that there is a real and persistent user demand and that sustainable design makes strong commercial sense.
\end{abstract}

Key words: Sustainable, building, offices, green, existing, attitudes, renovation, revitalization.

\section{Introduction}

In 2007 a series of interviews were carried out by the author to obtain an insight into stakeholder perceptions and attitudes to sustainable development and green buildings in general and green redevelopment of existing office buildings in particular. Those consulted included representatives from building developers, building owners, realtors, specialist consultants and tenant organizations. The results of this survey were documented in previous papers by the author [1-3]. Because of the limited numbers of people interviewed, the information obtained could not be regarded as

Corresponding author: John Bloomfield Storey, associate professor, research fields: sustainable architecture, construction material stewardship, sustainable renovation. E-mail: john.storey@vuw.ac.nz. statistically meaningful but did provide an indicator of shifting developer/owners attitudes.

Though the insights gained in the interviews were very valuable, it is difficult to reconcile opinion with fact in interview situations. With that in mind, an analysis of a series of built outcomes was undertaken to provide more unbiased and compelling evidence of whether or not attitudinal shift had in fact occurred.

\section{Context}

In order to appreciate the significance of the case study examples explored in this paper, it is necessary to understand something of the changes and the reasons behind the changes that have occurred in the office building sector in New Zealand in recent times. The 1989 stockmarket crash and coincidental public service downsizing hit the country's commercial development 
Code. After the 1989 stockmarket crash there was suddenly a glut of office space. Very little new office space was built in the subsequent 15 years apart from a few high quality developments. Virtually all office related building work during that period was the upgrading of existing buildings; but this work was essentially confined to the improvement of a building's image and appearance, improving lift waiting times and improving lighting efficiency.

Most commercial office building in New Zealand occurs in just two centres: Wellington and Auckland. Wellington is New Zealand's capital city and about $60 \%$ of large lettings of office space are occupied by government departments, quasi government agencies and state owned companies. Government policy is that government departments and agencies lease space rather than own their own buildings. Auckland by contrast is the nation's commercial hub and offices here are primarily leased out to private sector business.

\subsection{Government Leadership}

For a number of reasons $[1,2]$ central government assumed leadership in making New Zealand's built environment more sustainable. Government's financial support for the establishment of the NZ Green Building Council (NZGBC) mid decade was crucial in this respect. A pronouncement by the Government in 2007 [4] that all future public service department leasing was to be in 4 or 5 star Green Star NZ rated buildings, consolidated and institutionalised the position of the NZGBC and its Green Star building assessment system. The new Building Act [5] had a strong sustainability focus and applies equally to both new and renovated existing buildings. In February 2007 [6] the Prime Minister announced the government's intention to establish a carbon neutral public sector and stated that it would use its purchasing power to drive the changes necessary to accomplish this paradigm shift. Government purchasing departments were directed to modify their purchasing protocols and to extend preferential status to materials, products and companies that can provide evidence of a substantive "green” profile. As central government spends about 25 billion dollars a year these directives had a profound effect on the whole of the building sector.

Other directives included the adoption of passive solar principals in the design of all new government buildings from January 2009 [7]; the requirement that all new government buildings were to meet a minimum 5 star Green Star NZ rating from 2012 [8] and that all public service departments were to accelerate the adoption of sustainable building practices [9]. A Waste Minimisation Act [10] was passed into law in 2008. Within the public service the Govt ${ }^{3}$ compact was established, to undertake practical action, learn from and share knowledge with other participating agencies, link people together and provide technical information and case studies in the pursuance of financial, social and environmental sustainability in the public sector.

Taken together these measures sent a strong message not only to the whole of the national government sector but also to local government and quasi public agencies. By 2008 there were many positives. Government had a strong long term vision for the development of New Zealand in the 21st century, with sustainability as one of the cornerstones in their strategy.

And then there was a change in Government! And then there was the 2008 global financial crisis! And things changed, drastically.

Even before the GBC the new government had established a very different set of priorities and agendas. "Sustainability", both as a term and a concept fell out of favour in government circles. The new emphasis is on resource efficiency and affordable development. Many of the previous government's sustainability measures were dropped, put on hold or emasculated. This includes many of those related to buildings and the environment. After the GFC the government brought in austerity measures and cut public service budgets.

The Govt ${ }^{3}$ initiative has been terminated. The sustainability directives concerning government 
building leases, new government buildings and purchasing have been dropped. On the other hand the new government has passed an Emissions Trading Scheme and fully supports The Waste Minimisation legislation. However, the strong commitment to a sustainable future for New Zealand and the visionary measures set in motion by the previous government have now been replaced by more pragmatic, short term aspirations. Government leadership in the sustainable building field has fallen away over the last two years.

\subsection{The Commercial Sector}

The private commercial sector was slow to adopt "green" building design. However, with so many "blue chip" government leases at stake in the middle of the decade many of the larger developer/building owners built Green Star compliant new buildings. More tenants in the private sector are recognising the long term financial and productivity benefits in leasing "green" buildings. Realtors too are aware of this shift in user demand. By 2007, Hince [11] of CB Richard Ellis Property Managers in Wellington was able to assert that, "building tenants are seeking higher quality accommodation, with environmentally sustainable features becoming increasingly important (and I) would expect to see a high vacancy in the lower quality of building. By acting now and upgrading and refurbishing these buildings the owners should go some way to alleviating this risk."

All the building sector stakeholders consulted by the author agree that by 2007 the commercial sector had begun to take a much greater interest in and had become much more aware of, the opportunities inherent in the "green" building development [1].

New Zealand weathered the 2008 financial crisis reasonably well in many respects. A few financial companies failed, but all the major banks survived without having to receive government bailouts. However, many organizations downsized or did not replace staff and the nature of the office letting market changed dramatically from one where there were very low vacancy rates to one of abundance, considerable tenant movement and competition to let lease expired accommodation.

\section{Attitudinal Shift}

Whatever the actual merits of creating and occupying "green" buildings, it is the perceptions and attitudes of the decision makers, the building developers, owners and tenant organizations and occupiers that make the difference between whether a "green" building remains an idea or becomes a physical reality. The results of the survey conducted by the author in 2007 [1, 3], suggested that a very significant positive shift towards ESD in the building sector had occurred over the previous eighteen months, with respect to the sustainable refurbishment of existing office buildings and that this change was gathering momentum. This was a consensus view amongst a group that often had very different notions about the economic and technical feasibility or even the desirability of such refurbishment programmes.

There was also general agreement amongst the surveyed group that this move to "green" had occurred largely due to strong government leadership, with the government directives, pronouncements and interventions mentioned above being identified as key drivers in achieving this attitudinal transformation.

The group surveys were much less unified in their attitudes to the sustainable refurbishment of existing buildings. The building developer/owners consulted were concerned that ESD upgrades were more expensive than conventional upgrades and that tenants were not prepared to pay for the extra features incorporated. They tended to favour replacement rather than refurbishment. Realtors on the other hand were convinced that there was a tenant demand for green premises and were concerned that unless existing buildings were provided with sustainable design credentials they would become increasingly difficult to let and might even be impossible to let once the new sustainable buildings currently under construction 
came on-stream. They saw this as a particular problem in Wellington with its high percentage of government leased buildings. Tenant representatives were concerned that there was currently an insufficient supply of "green" space to rent. The government representative and the workplace strategist considered that the country could not afford to replace all its existing buildings either from a financial or a cultural perspective and that retained buildings needed to have enhanced sustainability performance [12].

All of these comments are valid and, in a way, all are correct. Existing buildings have to achieve the same performance standards as new buildings to be awarded a Green Star rating in New Zealand. This does make them more expensive than conventional office building upgrades. Much of the upgrading is hidden and tenants sometimes find it difficult to comprehend the value to them of such upgrading and are therefore reluctant to pay premium rates or enter into green leasing arrangements. The Green Star system only rates whole buildings so that piecemeal upgrading attracts no marketing accolade and with New Zealand's prevalent multi-tenanted building environment wholesale refurbishment becomes very complex. Sustainability performance standards for new buildings are already well above the performance standards achieved in existing buildings and when the new Building Act is finally enshrined in the Building Code increased disparity is certain. New Zealand cannot afford to replace all its existing buildings or leave them to underperform. Building replacement rates even before the stockmarket crash were estimated at $1.5 \%$ per annum and this figure has fallen significantly in the last two years. Existing buildings unless upgraded will increasing retard average performance gains across the sector and slow the realization of higher performance targets. Therefore, there is a strong need for green office building refurbishment. New Zealand is not a rich country and must make the best use of what it has.

For most developer/owners and tenants interest and demand has been focused on new building developments and many stakeholders remain unaware of the opportunities that exist in relation to existing offices buildings. This is in part due to the fact that many developer/owners are very risk adverse and tend to be followers rather than leaders and are difficult to persuade to move along a different path however much sense it makes. Yet there has been movement in the sector as is illustrated by the three case study examples in this paper.

\section{Case Studies}

The Chaffers Dock case study shows the reality of commercial development in the early 21st century while the Department of Conservation Headquarters and the 21 Queen Street developments illustrate the physical outcomes that have resulted from the changing attitudes to revitalising existing office buildings that incorporate strong ESD features, by forward looking commercial organizations.

\subsection{Chaffers Dock (2003-2006)}

The original L-shaped, Herd Street Post and Telegraph building was designed by Edmund Anscombe in a severe art deco style and is recognized as one of Wellington's key heritage buildings. Completed in 1939, the building was used by the Post Office until the late 1980s. Its future at that stage was uncertain and was the subject of prolonged and often acrimonious debate for the next fifteen years. Today it has been converted into 64 apartments on the upper floors with a mixture of restaurants, cafes, galleries and retail on the ground floor. It was renovated without any attention being paid to environmentally sustainable design (ESD). The main issue for the developers throughout the design stage was one of obtaining planning consent. Other constructional measures were undertaken to comply with the current Building Regulations or to help sell the apartment units. At this time developer/owners were not interested in incorporating green features into their buildings, and the general public was not demanding such features in 2003 when the design was commissioned. 
Nevertheless in some respects the consented building design has a number of inherently sustainable features. Foundations, superstructure, concrete floor slabs, concrete façade are all retained in the renovated building. Calculations carried out by the author suggest that this amounts to about 6,800 tonnes of raw materials. If these materials had been landfilled, about 1140 truck journeys to and from the local landfill, and about $4000 \mathrm{~m}^{3}$ of landfill space would have been required. In addition new materials would have had to be deployed which, though probably lighter in weight, would have probably been of similar overall embodied energy to the demolition materials. Additional benefits of this approach were the saving of months of noise and dust from demolition work and the time and cost of new site, structural and façade work. Energy savings of the order of 16.2 million megajoules were made by adopting this strategy [13].

The Herd Street building is serendipitously an excellent climate modifying passive design form, a high mass construction with a high irradiation aspect and a shallow planform, which in New Zealand's relatively benign climate, allows natural ventilation (Fig. 1). From the landside of the development its cultural integrity is maintained but from the sea side additions diminish the building's historic identity (Fig. 2).

No deliberate concessions were made to sustainable building practices, features or materials in any new work undertaken beyond those required under the NZ Building Code.

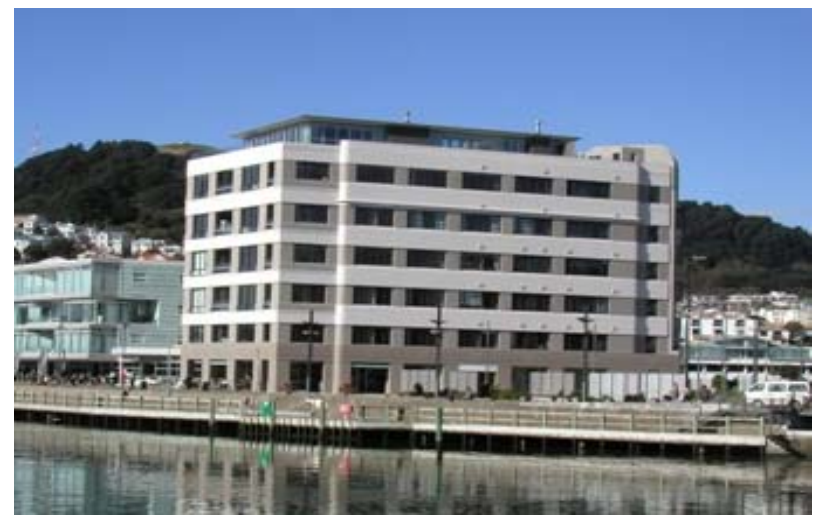

Fig. 1 West façade original building high mass climate moderating type original façade and structure retained.

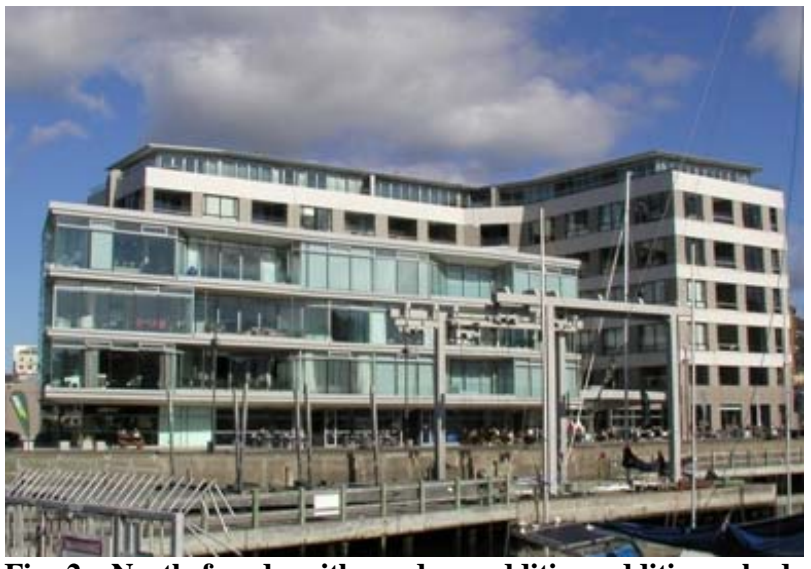

Fig. 2 North façade with modern addition additions shade most of original north façade reducing solar heating potential but protect the original building from severe northerly winds, photographs courtesy of mahoney developments.

\subsection{Department of Conservation Headquarters (DOC HQ) Building Wellington (2004-2007)}

The new Department of Conservation headquarters building is an outstanding example of what can be achieved with an existing building. The DOC HQ building was constructed using a redundant cinema complex as the base building. The headquarters building was designed to 5 star + Green Star Australia criteria, because, at the time there was no New Zealand Green Star rating system in place.

The brief called for minimizing energy consumption and water conservation, the use of environmentally preferred materials, high quality interior workplace environments and the optimization of operating and maintenance regimes. In 2004 when the 12 expressions of interest were invited by DOC from potential providers only three attempted to fulfil the DOC brief, the rest proposing a conventional building, arguing that there was no market for sustainable office accommodation in New Zealand, and that the extra costs involved were prohibitive. Only one of the three remaining three submissions sought to reuse an existing building.

The existing building response was quickly established as the one that best fulfilled the DOC brief and intentions and quickly became the preferred option.

In the end the scheme attracted a modest $12 \%$ owner 
and $10 \%$ tenant initial cost premium over a conventional building renovation but achieved a significant saving in both time and money over building a new building to the same standard [14]. No comparative figures are available between a new and a renovated building for this site, but an exercise carried out on the $\mathrm{CH} 1$ office building in Melbourne suggests that a new building would have cost nearly twice as much as a renovated building built to the same standard [15].

A “Green Lease” component, which recognized and compensated the developer for the extra initial costs involved, was agreed between owner and tenant. The building was completed in 2007. It is estimated that full cost recovery will occur about halfway through the initial 12 year lease period and from then on significant cost savings will accrue to both parties. The building is being extensively monitored and will provide good feedback concerning what is practically achievable. It has already helped to refine a number of green performance briefs for other existing office buildings.

53\% measured energy savings are currently being achieved over a standard office building, which for hybrid ventilated buildings is defined as building with a typical energy use of $240 \mathrm{kWh} / \mathrm{m}^{2}$ [16]. This comfortably exceeds the $40 \%$ energy saving target set in the brief. This energy saving is achieved through the use of a mixed mode ventilation system that utilises natural ventilation as shown in Fig. 3 combined with an active chilled beam system, BMS controlled night purging and spring and autumn cycles where natural ventilation becomes the primary conditioning mode, a fully addressable lighting system that uses occupancy detection and daylight harvesting, high efficiency fluorescent and LED lamps and a solar heat pump hot water system [17].

Rainwater collected from the roof (Fig. 4) is stored in 65,000 litre basement tanks and currently supplies $77 \%$ of the building's non-potable water demand. Sensor taps are used to further reduce demand. Sustainable internal fittings and materials were selected with special care being given to avoiding PVC and minimising volatile organic compounds and formaldehyde. NZ Environmental Choice certified products were used wherever possible and The Ministry for the Environment's Sustainable Fitout Guide [18] was used as a guidance document for the interior design. Linoleum flooring, low emission paints, Wavin AS non-PVC recyclable plumbing pipes, Laminex Greenfirst panel materials, Formway furniture, sustainable plantation grown timbers, and low environmental impact carpet tiles were just some of the materials and products incorporated. Stairs were designed to be prominent, wide and attractive and lifts hidden away to encourage walking between floors.

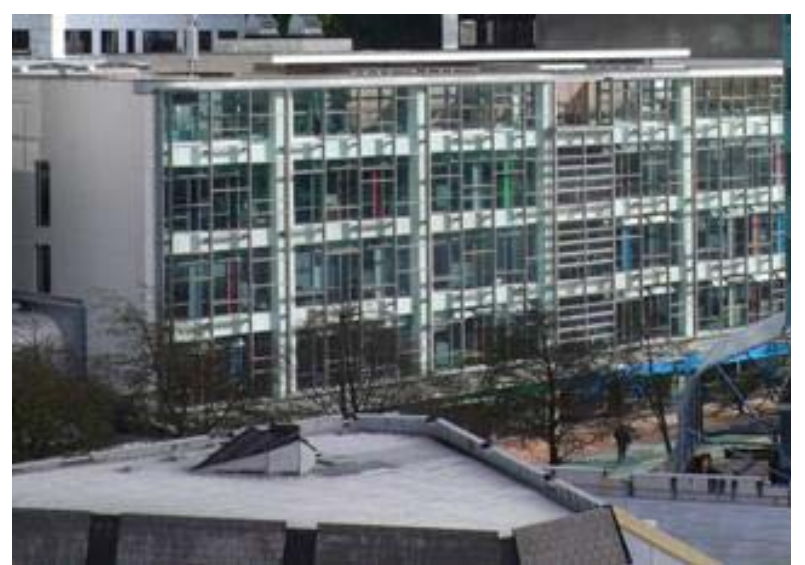

Fig. 3 New double façade. A simple inexpensive system using off-the-shelf curtainwall components permit operable windows and natural ventilation even in Wellington's often severe wind conditions Photo VUW.

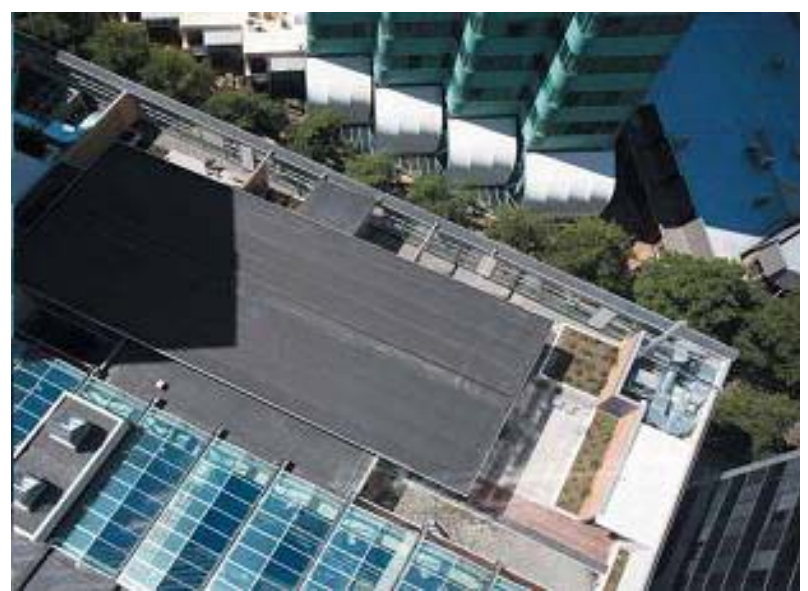

Fig. 4 Atrium and roof garden + staff terrace café Atrium provides natural lighting to the centre of the building and stack effect ventilation exhaust. Over time solar hot water, p.v. arrays and additional wind turbines are planned Photo courtesy of Department of Conservation. 
Separate recycling bins for paper, inorganic, organic, glass, plastic and metal wastes are located in utility rooms or kitchen areas.

This building is an excellent demonstration of what can be achieved by a determined and knowledgeable client in combination with a sympathetic developer/owner and caring occupants. The building was open to the public after completion and still attracts many visitors each year. Its success has been instrumental in persuading many developers and clients that renovation was a viable option and this example combined with the government declaration that all future government leases would be in $5 \mathrm{NZ}$ Green Star rated buildings can probably be credited in large measure with the shift in developer attitudes that has ensued.

\subsection{Queen Street, Auckland (2007-2009)}

Original dating from the 1970s, 21 Queen Street is located in the heart of the Auckland Central Business District. It was originally built to the lowest legal construction and space standards at a time of widespread speculative development when space shortages in the office sector meant that even poor quality office buildings could find tenants. This is no longer the situation and over the years this building and many more like it have become increasingly difficult to tenant. In the case of 21 Queen Street this led to a prolonged period of decline that has affected not only the building itself but also the area surrounding the building at street level.

Many developers/owners would have demolished the building and started anew. However, the architects ran a series of scenarios and were able to demonstrate to the building owners that a major renovation rather than starting new was the best overall option both in terms of time and cost. In this case, an enlightened client combined with a skilled and imaginative design team found ways to retain the building's original use and upgrade it to current standards. This has been achieved at a fraction of the cost and time compared with building a new building of equivalent standard.

This building has now received a PCNZ "A" grade rating and an NZGBC 5 star Green Star NZ "New Zealand Excellence” design rating [19]. The 5 Green Star NZ rating, equivalent to LEED Gold, fulfilled the requirements for government office leasing in Central Business Districts and provided the building with a strong marketing cache.

The use of energy efficient lighting, chilled beam space conditioning, water saving technologies, the incorporation of environmentally friendly materials, the building's location adjacent to Auckland's transport hub, harbour and expansive city views and the fulfilment of NZGBC project management criteria all made strong contributions to the award of Green Star points.

One of the key design decisions was the removal of the original heavy concrete spandrel panels, as shown in Fig. 5, and their replacement with a high performance solar and energy control double glazing façade system, as shown in Figs. 6 and 7, that improved energy efficiency, daylighting and glare control and reduced interior traffic noise, as well as presenting a modern image and increasing net lettable area.

The lighter weight of the curtain wall system permitted the addition of 4 extra floors while enabling the retention of the original foundations and structure. These changes allow the addition of an extra 4,500 $\mathrm{m}^{2}$ to the original $14,000 \mathrm{~m}^{2}$ of net lettable space. The existing core is retained and reused and this plus the thinner façade allow a gross to lettable area ratio $92.5 \%$ to be achieved. Together these factors make a major difference to the commercial viability of the renovated building.

The modern, high performance, pressure equalised double glazed curtain wall system (Figs. 6 and 7) incorporates heat absorbing solar control glass externally and low-E glass on exterior facing surface of the inner glass pane. This double glazing system permits $51 \%$ light transmission and gives a shading 
index of 0.29 with a maximum external reflectance of $6 \%$ and a maximum interior reflectance of $7 \%$.

Rainwater harvesting and storage is incorporated into the design. Harvested water is used for toilet flushing. Low flow water taps are provided to all bathroom areas. Energy efficient, single tube T5 tri-phosphor fluorescent lamps are currently specified. These are semi recessed to illuminate and bounce light off the ceiling. The lighting system is designed to allow for the incorporation of LED strip lights when these become available on the NZ market. This will significantly reduce energy demand. The energy efficient chilled

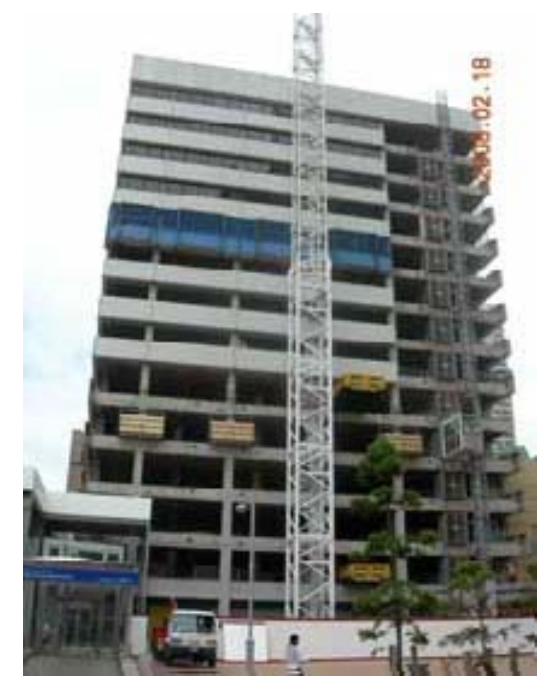

Fig. 5 Removal of heavyweight concrete panel façade.

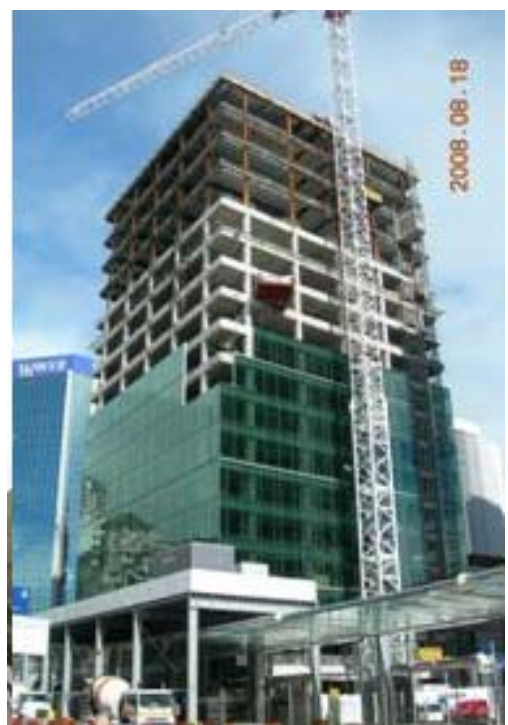

Fig. 6 New lightweight double glazed façade system allowed 4. Extra floors to be added.

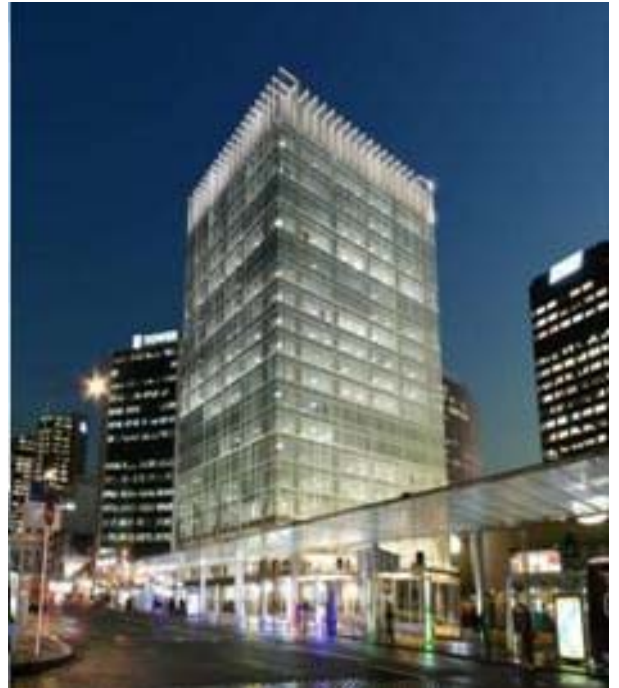

Fig. 7 Finished building with glazed pedestrian covered way. Photographs courtesy of Peddle Thorp Architects.

beam air conditioning system uses $100 \%$ fresh air and incorporates an energy recovery interface between the exhaust and inlet air intakes. Base building energy demand has been calculated at $54.7 \mathrm{kWh} / \mathrm{m}^{2}$, which is roughly $40 \%$ of the typical air conditioned base building energy load [15].

From a technical viewpoint, this building is most significant as an example of what is achievable reusing a 1960-1990 building. Structural elements have always been carefully controlled and built to high standards in New Zealand to comply with strict earthquake and wind loading criteria and so were able to be reused. This in itself saved months of construction time and significantly improves the building's embodied energy profile. In this type of building the massive, reinforced concrete structure, floor slabs and foundations conventionally contribute $75 \%$ or more to the building's total embodied energy content. Not all buildings of this era can be refurbished in this way; core size is crucial. In this case the structural core was large enough to take all the extra servicing requirements and new lifts able to meet the reduced lift waiting times demanded by today's tenants. This is a critical factor, if core reuse had not been possible it is unlikely that the scheme would have been financially feasible [19]. 


\section{Discussion}

The three case studies illustrate just how much of an attitudinal shift has occurred across the commercial office sector over the last 7 years. The Chaffers Dock building (2003-2006) is a historically important art deco building but was considered redundant and unsuitable for refurbishment by most developers. It was only through the fierce resistance of city residents and particularly of Wellington Waterfront Watch that the building was saved from demolition.

The brief and specification for Chaffers Dock development makes no mention of sustainable features in any of its briefing documents or its sales literature. The resource conservation resulting from the retention of the heavyweight structure and façade and the climatic moderating effect of the high mass building was purely serendipitous. Indeed in 2003 developers were highly sceptical of environmentally sustainable design without knowing anything about it. They were comfortable in their ignorance, tended to see only the extra costs and the extra risk involved and not the potential benefits. They considered that there was no demand for sustainable office buildings. This laissez faire attitude was reinforced by the fact that high office occupancy rates have been normal throughout the 21st century in New Zealand. In that climate there was, almost inevitably, an element of complacency in developer/owner thinking. They could not see why they should do anything different while they could easily let conventional buildings.

This is a demonstration of a classic dilemma, that of developers/owners not creating sustainable office environments because they could see no need or demand and occupants not being able choose between conventional and sustainable office buildings because there was no supply of sustainable lettable space.

A major shift in thinking occurred with the completion of the Department of Conservation's headquarters building in 2007. In proving that a truly sustainable building renovation could be built at a modest on-cost that was recoverable by all parties involved in a short period of time, the DOC building blazed the trail for others to follow. Shortly after the completion of the DOC HQ building a new sustainable headquarters building was completed for Meridian Energy, a state owned company. This was the first NZGBC 5 star Green Star NZ rated building.

These two buildings demonstrated what could be done and set the new benchmarks for both existing and new office developments. The announcement that from July 2008 all new government leases in CBDs would be in 5 NZ Green Star rated buildings added a significant impetus to attitudinal change; but without these two successful exemplar buildings it is doubtful whether government would have declared this intention and even more doubtful that building developers and owners would have believed in the commercial feasibility of such enterprises. These buildings also were very persuasive in convincing tenant organizations and occupants of the value of inhabiting high quality environmentally friendly premises.

It is in Auckland that the final case study is located and where the most recent shift in developer's attitudes is demonstrated. The redevelopment of 21 Queen Street incorporates a number of "green" features but none that is particularly innovative, and indeed several are essentially mainstream in many new CBD office developments. Its real significance lies in the fact that the redevelopment has been carried out in an office building built in the 1970s. Office buildings built from the 1970s through to 1990s in New Zealand were generally underspecified, minimalist and have very low floor-to-ceiling heights that were thought to prohibit renovation to meet current tenant expectations for office occupancy. However, the refurbished 21 Queen Street building is both a PCNZ Grade " $\mathrm{A}$ " grade building and has been awarded a 5 star Green Star NZ rating. Furthermore, the work was carried out at a fraction of the cost and time required to construct a new building of similar standard. 21 Queen Street is also important because the work was commissioned by one 
of the largest commercial building developer/owners in Australasia, AMP Property Trust, an organisation that is well respected in the commercial office sector. Its success will undoubtedly persuade and encourage other, more conservative building owners to look again at the opportunities provided by the 70-90 generation of buildings.

2008 was a time of great uncertainty and turmoil and some feared that all the gains made and the momentum established might have been lost with regard to environmentally sustainable design. As it turned out the effects of the GFC in New Zealand were not as severe as they were in many other parts of the world. Office buildings that had been started before the onset of the financial crisis have been completed and others, particularly at the high grade sector of the market, have been commissioned and built. Today virtually all new office developments incorporate strong ESD features. Some developers have disappeared, others have placed office development on hold, but the stronger development companies have seized the opportunity of operating in a favourable contractor climate to create high quality office developments. In the last year New Zealand's first 6 star Green Star NZ (LEED Platinum equivalent) assessed building buildings have emerged, one of which is the revitalization of Christchurch's Civic Offices.

A recent, comprehensive tenant survey of New Zealand tenant perceptions and attitudes, carried out by ACA Research for Colliers International [20], identifies that excellent indoor air quality and thermal comfort and a high level of natural light were the most important building attributes in attracting and retaining staff. The survey also states that $69 \%$ of tenants indicated that they believed that staff expectations regarding workplace design have significantly changed in the last three years. The top three changes in staff expectations are identified as: a 31\% increase in expectation of new and modern facilities; a 22\% increase in the belief that air quality is important; a increase in the perception by that staff are more environmentally aware and that 21\% expect more natural lighting and good quality artificial lighting.

All of these staff perceptions and expectations would be met, almost as a matter of course, by a revitalized Green Star rated building. In the depressed market conditions and with high quality new buildings still coming onto the market, many tenants are seeking to take advantage of their temporary, strong renting position to move to better quality premises, at no greater cost at lease-up. As many tenant organizations are now convinced that greener premises aid with staff retention, reduced absenteeism and increase productivity, demand for high quality green space is rising despite the generally depressed market.

\section{Conclusions}

In the author's attitudinal survey it was recognized that the numbers involved were too small to be able to draw more that tentative conclusions. Similarly the building case studies represent buildings at the very forefront of commercial building sector thinking at their time of construction. They illustrate the feasibility of such development not the norm. Nevertheless there seems to be a clear, demonstrable and positive attitudinal shift by decision makers concerning the achievability and merits of green building revitalization over the last 7 years.

In the earliest of the case study buildings, started on site in 2004, no consideration is given by developer, owner or design team to sustainability issues and there appears to be no user demand. In the second which started on site only one year later sustainable design is very prominent, but is largely tenant driven, albeit with the active and enthusiastic support of the developer and design team. The final case study building was started on site in 2007. This development is developer/building owner; driven by the conviction that there is a strong tenant demand for "green" buildings and that sustainable design makes strong financial sense. The three case study examples clearly reinforce the perception that positive attitudinal shift 
has indeed occurred within the developer/building owner community with regard to the desirability and merits of green office refurbishment.

Due to the policies and strategies introduced between 2005 and 2008 by the previous Government, building developers and manufacturers were obliged to take sustainability seriously. Quite a number of high quality green buildings were commissioned and built during this period. Many of these buildings were for government departments in the early days, but as developers, building owners and tenants became aware of the merits of such buildings other organizations, particularly those with an international presence in the market place, also began to demand high quality green space.

Concurrently developers seem to have largely lost their fear of green design due in no small measure to the success of the green prototypes mentioned elsewhere in this paper and the increasingly competitive letting market. Design teams and builders have also gained knowledge, experience and confidence in their ability to deliver successful green outcomes. Manufacturers have now started to sell green products on a competitive price basis. All this is reflected in reduced cost premiums for green building projects.

This new paradigm shift has been tested by the recent sharemarket crisis and survived. It might reasonably be inferred that the stimulation of the market by Government laws, policies, and declarations in the mid years of this decade and the widespread international recognition of the value of green buildings have together been instrumental and successful in the development of new benchmark standards for commercial buildings. The fact that neither government abrogation of its leadership role nor the global financial crisis has not unduly damaged the movement toward a greener built environment in New Zealand is a testimony to the strength of the fundamental shift that has occurred in the building sector towards green building outcomes. It would appear that the change in developer/building owner attitudes is both profound and embedded. Indeed the ante is rising with the recent emergence of New Zealand's first 6 star green buildings.

Leadership is now firmly in the hands of the private sector and to a lesser extent local government. This outcome was in fact what the previous government had set out to achieve in the early years of the 21st century. It tried unsuccessfully for two years, at that time to encourage industry to take up a leadership position before deciding that government leadership was the only way to overcome industry mistrust, complacency and conservatism and achieve the required attitudinal shift.

The current government, while it does not see sustainability in the building sector as a priority target, in the same way as the previous government did, is not actively against it. It is likely that with tighter budgets and the significant staff downsizing that is currently occurring within the public service, government departments will have to provide strong evidence of budget savings, if they wish to move into high end green buildings, which it has to be said is not an insurmountable barrier if Treasury will agree to a medium investment return term.

For most of the 21st century demand for office space in New Zealand has exceeded supply but currently the reverse is true and the buildings that are easiest to let at a reasonable rental return are those with strong environmentally friendly credentials. Downsizing of staff numbers means a more competitive space leasing environment. However, those building owners that have had the foresight to develop high quality "green" buildings are likely to have a competitive edge as tenant organizations are increasingly favouring green space letting [20].

As the migration into higher quality, often green space gathers momentum, a considerable quantity of older, poorer performing existing office buildings are left behind. The choice here is to demolish, upgrade or to convert them into apartments. Increasingly apartment buildings are being purpose built and demolition of office buildings is historically 
surprisingly rare in New Zealand, which tends to suggest that upgrading could well become the preferred option.

As the market recovers and employment rises these building are likely to require upgrading in order to meet rising tenant and employee expectations. As observed in the Colliers International Tenant Survey [20], tenant awareness and expectations with respect to the incorporation of "green" features into buildings are rising rapidly. Tenants are now aware of the existence and availability of "green" accommodation and increasingly want to occupy "green” space.

Market conditions, the oversupply of office space and tenant abandonment of poorer performing buildings far from being a negative happenstance, in fact provides both a unique window of opportunity and an imperative to upgrade these buildings in a comprehensive manner rather than piecemeal as has often been the case in the past. Developers have taken note as the market gradually corrects itself over the next few years will perforce need to respond to user demand if they wish to let their lower end office buildings.

There is still a measure of uncertainty about what will happen to existing office buildings and the timescale involved, but with a significant number of successful existing office building revitalization models now in place, significant and apparently enduring shifts in tenant and developer attitudes, greater ability and capacity to design and construct green buildings in the building industry, a growing belief that NZ has turned the corner in terms of the economy, falling unemployment (currently 6.6\%), firm indications of an improvement in the office letting market and a the gradual emergence of an upbeat attitude towards office development throughout the industry, it is a time for optimism.

\section{Acknowledgements}

The author sincerely thanks the following people who generously contributed their valuable time and information used in the preparation of this paper:
Grant Baker, Department of Conservation. Richard Burrell, Building Developer-Owner, Director, Building Solutions Ltd. Peter Dow, Workplace Strategist, Director of Dow Group Ltd. Phil Humphrey, Realtor, Colliers International Ltd. Wade Jennings, Peddle Thorp Architects. Robert Lang CEO AMP NZ Office Trust. Mark McGuiness, Building Developer-Owner and Managing Director, Willis Bond Ltd. Alan McMahon, Director (Research), Colliers International. Georgia Myers, Building Valuer, National Sustainability Manager, Jones Lang LaSalle Ltd. Ian Page, Building Economist BRANZ. Christopher Wood, Senior Advisor, Sustainable Industry Group, Ministry for the Environment.

\section{References}

[1] J. B. Storey, Overcoming the barriers to improving the sustainability of existing commercial buildings, in: Conference Portugal SB07, Sustainable Construction, Materials and Practices-Challenges of the Industry for the New Millennium, Lisbon, Portugal, 2007.

[2] J. B. Storey, Resource conservation in existing commercial office buildings, in: Conference CESB 07, Central Europe towards Sustainable Building, Prague, Czech Republic, 2007.

[3] J. B. Storey, Improving the sustainability of New Zealand's existing commercial office buildings, in: Conference SB07 NZ, Transforming Our Built Environment, Auckland, New Zealand, 2007.

[4] Govt, Cabinet Minutes CAB Min (07)18/7, Cabinet Office, Wellington, New Zealand, 2007.

[5] New Zealand Government, Building Act (2004), Government Publications, Wellington, New Zealand. 2004.

[6] Govt, Cabinet Paper POL (07)131, Cabinet Office, Wellington, New Zealand, 2007.

[7] Govt, Cabinet Minutes CAB (08)24/11, Cabinet Office, Wellington, New Zealand, 2008.

[8] Ministry for the Environment, New Zealand Energy Efficiency and Conservation Strategy (NZEECS), Wellington, New Zealand, 2007.

[9] Govt, Cabinet Minutes CAB (06)34/16, Cabinet Office, Wellington, New Zealand, 2006.

[10] New Zealand Government, Waste Minimisation Act (2008), Government Publications, Wellington, NZ, 2008.

[11] M. Hince, Office space demand is still growing, Dominion Post Newspaper, 23rd June 2007, Wellington, New Zealand, 2007. 
[12] J. B. Storey, Relocation and reuse of herd street post office, confidential, Unpublished Consultants Report, Wellington, New Zealand, 1995.

[13] G. Baker, Personal communications, 2007.

[14] M. Pierce, Personal communications, 2007.

[15] Property Council of New Zealand, Office Building Energy Consumption Survey, Auckland, New Zealand, 2000.

[16] Ministry for the Environment, DOC HQ Case Study, 2008, available online at: http://www.doc.govt.nz.
[17] Ministry for the Environment, Sustainable Fitout Guide MfE Publication ME703, Wellington, New Zealand, 2005.

[18] New Zealand Green Building Council, Green Star NZ Office Design v1, Auckland, New Zealand, 2007.

[19] Peddle Thorp Architects/AMP NZ Office Trust, NZ GBC Green Star Assessment Submission, 2008.

[20] ACA Research/Colliers International Research, Colliers International Office Tenant Survey, Auckland New Zealand, 2010. 